\title{
Correction to: Integrative taxonomy and molecular phylogeny of three poorly known tintinnine ciliates, with the establishment of a new genus (Protista; Ciliophora; Oligotrichea)
}

Rui Wang ${ }^{1,2,5}$, Yang Bai ${ }^{1,2}$, Tao Hu${ }^{3}$, Dapeng $\mathrm{Xu}^{4}$, Toshikazu Suzuki ${ }^{5}$ and XiaOzhong $\mathrm{Hu}^{1,2^{*}}$

\section{Correction to: BMC Ecol Evol (2021) 21:115}

https://doi.org/10.1186/s12862-021-01831-

8

Following the publication of the original article [1], the authors have flagged that on page 2, "Antetintinnopsis hemispiralis" was mistakenly replaced by "Antetintinnopsis karajacensis" as type species.

The original article has been corrected.

\section{Reference}

1. Wang R, Bai Y, Hu T, Xu D, Suzuki T, Hu X. Integrative taxonomy and molecular phylogeny of three poorly known tintinnine ciliates, with the establishment of a new genus (Protista; Ciliophora; Oligotrichea). BMC Ecol Evol. 2021;21:115. https://doi.org/10.1186/s12862-021-01831-8.

\section{Publisher's Note}

Springer Nature remains neutral with regard to jurisdictional claims in published maps and institutional affiliations.

\section{Author details}

${ }^{1}$ College of Fisheries, \& Key Laboratory of Mariculture, Ministry of Education, Ocean University of China, Qingdao 266003, China. ${ }^{2}$ Institute of Evolution \& Marine Biodiversity, Ocean University of China, Qingdao 266003 , China. ${ }^{3}$ Laboratory of Protozoology, Key Laboratory of Ecology and Environmental Science in Guangdong Higher Education, South China Normal University, Guangzhou 510631. China. ${ }^{4}$ State Key Laboratory of Marine Environmental Science, Institute of Marine Microbes and Ecospheres, College of Ocean and Earth Sciences, Xiamen University, Xiamen 361102, China. ${ }^{5}$ Faculty of Fisheries, Nagasaki University, 1-14 Bunkyo-machi, Nagasaki 852-8521, Japan.

Published online: 11 August 2021 regulation or exceeds the permitted use, you will need to obtain permission directly from the copyright holder. To view a copy of this licence, visit http://creativecommons.org/licenses/by/4.0/. The Creative Commons Public Domain Dedication waiver (http://creativeco mmons.org/publicdomain/zero/1.0/) applies to the data made available in this article, unless otherwise stated in a credit line to the data. 